\title{
Re-Mapping the Indian Ocean in Amitav Ghosh's Sea of Poppies
}

Sabine Lauret

\section{(2) OpenEdition \\ Journals}

Electronic version

URL: https://journals.openedition.org/ces/7870

DOI: $10.4000 /$ ces.7870

ISSN: 2534-6695

Publisher

SEPC (Société d'études des pays du Commonwealth)

\section{Printed version}

Date of publication: 1 September 2011

Number of pages: 55-65

ISSN: 2270-0633

\section{Electronic reference}

Sabine Lauret, "Re-Mapping the Indian Ocean in Amitav Ghosh's Sea of Poppies", Commonwealth Essays and Studies [Online], 34.1 | 2011, Online since 16 November 2021, connection on 01 December 2021. URL: http://journals.openedition.org/ces/7870 ; DOI: https://doi.org/10.4000/ces.7870

\section{(c) (†) $\odot$}

Commonwealth Essays and Studies is licensed under a Licence Creative Commons Attribution - Pas d'Utilisation Commerciale - Pas de Modification 4.0 International. 


\section{Re-Mapping the Indian Ocean in Amitav Ghosh's Sea of Poppies}

With Sea of Poppies (2008), Amitav Ghosh re-enacts the history of the first wave of the Indian diaspora. He gathers many different characters on a ship heading for Mauritius Island. On board they learn how to manage change and how to live with their fears and dreams. Crossing the Indian Ocean, the characters are bound to be caught in a translation movement which makes cultures and languages collide. This paper analyses how Ghosh redefines migrancy through the prism of indentured labour, illustrating how the scattering movement of the diaspora and the confluent drive of globalisation intersect.

Amitav Ghosh, like other writers such as Bharati Mukherjee and Jhumpa Lahiri, is part of what Elleke Boehmer calls "migrant literature" (11). His writing focuses on interstitial spaces where characters travel, and the topos of the journey prevails in his fiction. In The Shadow Lines (1988), characters travel between England and India, and between India and Pakistan; in The Hungry Tide (2004), they explore the Sundarbans Rivers. His diasporic characters are a lens to expose the world's globalisation and cosmopolitanism. Building upon Claire Chambers's analysis of Ghosh's first novel, The Circle of Reason (1981), I will focus on the motif of the journey as associated with labour. Chambers points out that the novel is peopled with faceless migrants going to Egypt hoping for a better life, and argues that Ghosh subverts the picaresque to expose globalisation (36). I contend that in Sea of Poppies (2008), he sets out to undertake a similar task as he focuses on Indian indentured labour. He brings together the destinies of migrants of the first-wave of the Indian diaspora. Against the historical backdrop of the looming Opium War (1839), Ghosh highlights the journey of coolies going to Mauritius. This first volume of a projected trilogy ${ }^{1}$ unravels as a saga and teems with colourful characters, most of whom will board the Ibis, Burnham's ship. Burnham, "the son of a Liverpool timber merchant" (68), is himself a successful merchant involved in the opium trade, which is the force that reconfigured the world at the time. The crew of the Ibis includes lascars (East Indian sailors), but also Zachary Reid, the American second mate, and the caricatural Doughty, the pilot. On board, the coolies, or indentured labourers, come from many different places, and among them Deeti emerges as a leading figure. She is the widow of an opium addict who flees with Kalua, the man who rescued her from sati. Signing an agreement - a girmit to emigrate as a worker in exchange for money - she becomes a "girmitiya." Mingling with the coolies, there is also Paulette, a French orphan, who is running away from her tutor, Burnham, the above-mentioned merchant, after he asked her to spank him. In this dense narrative, all the characters are migrants, fleeing from one thing or another, even before they start their journey on the Ibis, and each delineates a line of the plot. On the one hand, each character has his own story and represents a local identity. On the other, the Ibis stands for the vehicle of a movement that re-maps

1. The second volume, River of Smoke, published in 2011, has been widely acclaimed. The narrative opens on Deeti's new life in Mauritius. Yet Mauritius is no longer the epicenter of the narrative. Since the opium trade has taken over the coolie trade, China has become the main setting. 
the world and in particular the Indian Ocean. Further, the characters' individual journeys delineate the global impact of imperial rules.

Ghosh redefines migrancy through the prism of indentured labour, with characters who are literally translated, and the motif of the journey gives a particular impulse to the story. His characters are bound to cross the Kala-Pani, the Black Water, overcoming all their fears to make a fresh start. One has to keep in mind that, in Indian culture, the ocean is a threatening place. As Brinda Metha puts is, "according to Hindu belief, the traversing of large expanses of water was associated with contamination and cultural defilement as it led to the dispersal of tradition, family, class and caste classifications and to the general loss of a 'purified' Hindu essence" (5). Yet the fear of the migrants here is counterbalanced by their hope of a better life. Their destination, "Mareech-dip," "the Mauritius Islands," "les îles Maurice" (Sea of Poppies 126), appears as a compelling force of attraction that not only appeals to them but also to the colonisers. Using different names and the plural form, Ghosh emphasises that the island lures people to its shores and sets out to consider this idealised place as what polarises the narrative migration at work in the text. But one should also consider the publication of The Ibis Chrestomathy on Ghosh's official website which engages with the question of readability and points at another type of migration. Instead of a glossary, Ghosh provides his reader with a collection of passages from the dictionaries he compiled in his preliminary research. The novel is not only about migrant bodies, but also about migrant words. The migrancy of people needs to be considered as Ghosh's starting point to show that language is the epitome of migration. In Salman Rushdie's The Enchantress of Florence, language is compared to a disease. The traveller who goes to the Emperor "could dream in seven languages: Italian, Spanish, Arabic, Persian, Russian, English, and Portuguese. He had picked up languages the way most sailors picked up diseases" (10). Considering language as something contagious, I will look for symptoms of a mutable tongue, and show that the urge of migrancy is revealed in the way the characters and narrator speak. Grounding my analysis in Benveniste's theories on language, I will study the way people's stories prompt us to read the novel as "a palimpsest of movement, travel and inter-cultural crossing" (Dixon 12). First scrutinising how migration appears in the narrative, I will then show that Ghosh invites the reader to reflect on cultural and linguistic friction in the diasporic movement, which will help reveal the reader as the ultimate migrant of this inspiring novel.

\section{Narrative migrations}

Symbols of migration, and even more so of translation, abound in the novel. The first chapter opens with Deeti's vision of a "tall-masted ship" (3), which sets the tone of the narrative. Further, when Kalua comes to rescue her from the sati pyre, they escape on a raft on the Ganga. Even though the crossing of the Indian Ocean only starts in the third and last part of the novel, Sea of Poppies is a tale of migrants. In this regard, Deeti's perception of her hut is revealing: "it looked like a tiny raft, floating upon a river of poppies" (26). The characters drift in the narrative. The novel then could read as a travel journal in which, as often, Ghosh describes everything in minute detail. In the first part, Zachary sails the Ibis to Calcutta all the way from America. 
Some passages read as palimpsests, with traces of Conrad's Lord Jim and Coleridge's "The Rime of the Ancient Mariner." For instance, on the way to Calcutta many members of the crew die, leaving Zachary standing as the New Mariner, for he was taken on board as a carpenter in the first place. Yet, if Ghosh acknowledges the connection with Coleridge's ballad (see "Amitav Ghosh and his Sea of Poppies"), he emphasises even more his affiliation to Melville, especially to chapter 40 of Moby Dick which truly voices the cultural diversity on board of the ship. Ghosh pays homage to Melville's multi-ethnic crew which is composed of French, Dutch, Haitian and lascar sailors, among others.

The travel journal takes another turn in the third part, which is reminiscent of Les rochers de Poudre d'Or (2003), by Nathacha Appanah, a writer from Mauritius. In the first part of her novel, the reader follows the destinies of a group of characters crossing the Kala-Pani. The two novels share significant common points. For example, among the passengers of the Atlas, there is also a widow, Ganga, who refused to die on her husband's pyre. Like Deeti, she uses a different identity to board the ship. Appanah's novel undermines the idealised horizon with the conditions of the crossing. The coolies are dehumanised as shown by the food they are served which is referred to as dog food (89). Both narratives focus on the conditions of life on board the ship and on the notion of labour. The historiographical voice in Sea of Poppies thus emphasises the fact that people were "packed close together, like merchandise on a vendor's counter" (132). The narrator also exposes the "rationing of drinking water" (369), the chores and the abuses. What is more, both novels enhance the appeal of the island of destiny. In Appanah's narrative, the village of Poudre d'Or conjures up the image of fascination for gold. Mauritius Island is highly idealised only to be undermined in the second part of the novel. The sharp contrast between reality and fantasy is a way to exacerbate the suffering of the coolies. Ghosh, on the other hand, chooses to expose how the island was only an opportunity for profit for the colonisers. whereas in the coolies' minds, Mauritius is associated with frightening images of the jungle, to Burnham, it evokes the sugar-cane trade. Ghosh then goes one step further than Appanah, suggesting links between the coolie trade and slavery.

Engaging with the issue of indentured labour, Ghosh chooses to describe the moment of departure. He scrutinises a pre-diasporic people. Deeti's angst in front of the coolies/girmityas conjures up the "impossible mourning" which Vijay Mishra associates with diaspora (7-10):

She tried to imagine what it would be like to be in their place, to know that you were forever an outcaste; to know that you would never again enter your father's house; that you would never throw your arms around your mother; never eat a meal with your sisters and brothers; never feel the cleansing touch of the Ganga. (Sea of Poppies 67, emphasis added)

The repetition of "never" epitomizes the metaphorical death implied in the diasporic movement. But here, this death is overshadowed by the risk of impurity. In Indian literature, the Kala-Pani is often a dangerous, even taboo place. Ghosh's characters are haunted by the fear of loosing their caste. The Black Water is a nonplace, a "netherworld" (3), where life is threatened to be swallowed. "The water was as dark and still as the cloak of shadows that covers the opening of an abyss" (363). The 
immensity of the ocean contrasts with the size of the ship, and yet, contributes to the claustrophobic atmosphere in part III. The Ibis acts as a catalyst of fear and rumours:

The pulwar became a cauldron of rumours: it began to be whispered that their rations on the Black Water ship would consist of beef and pork; those who refused to eat would be whipped senseless and the meats would be thrust down their throats. On reaching Mareech, they would be forced to convert to Christianity; they would be made to consume all kinds of forbidden foods, from the sea and the jungle. (228)

The cauldron conjures up the image of an underground volcanic activity, of a devouring anxiety. The fear of impurity is crystallised in the transgression of food codes. Crossing the Kala-Pani corrupts the coolies' bodies and puts the world as they know it in jeopardy. Gloomy shadows loom on the horizon and Mareech-dip turns into a terrifying jungle:

The most frightening of the rumours was centred upon the question of why the white men were so insistent on procuring the young and the juvenile, rather than those who were wise, knowing and rich in experience: it was because they were after the oil that was to be found in the human brain [...]. The method employed in extracting this substance was to hang the victims upside-down, by their ankles, with holes bored into their skull. (228)

Images of torture and cannibalism fill the coolies' imagination. Yet, Paulette finds a way to abate the fears of her travel companions when she says: "On a boat of pilgrims, no one can lose caste and everyone is the same $[\ldots]$. [F]rom now on, and forever afterwards, we will all be ship-siblings" (328). The image of the ship as a mother figure pervades the whole narrative in different ways. To Deeti, the Ibis is an adoptive parent: "her new self, her new life, had been gestating all this while in the belly of this creature, this vessel that was Mother-Father of her new family, a great wooden mái-báp, an adoptive ancestor and parent of dynasties yet to come" (238). Besides, during the journey she finds herself pregnant, thus becoming a metonymy for the Ibis. As her body undergoes physical transformations, Deeti also reveals a new personality. She becomes a "Bhauji" figure, considered by the others as "their older brother's wife" (395). To some extent she embodies the redefinition of the status of women on board, for the traditional and patriarchal structures are no longer valid.

The ship is both a means of transportation and of transformation. It is bound to be the place where identities collide and are reshaped. The etymology of the word migration reveals that one of the possible roots of migrare is -mei, to change. The characters are transformed on board. Paulette, the French orphan, becomes Putlesharwi/Putli and poses as a Bengali woman, hiding behind her sari as a veil. People are not who they seem to be, as illustrated by the disgraced Raja of Raskhali, convicted as a criminal, or by Zachary who, "with skin the colour of old ivory" (10), is mistaken for a white man. The most impressive change though is Nob Kissin Pander's cross-dressing. This man, who is in charge of the coolies, turns into a matriarchal figure as he becomes increasingly effeminate over the course of the story. By the end of the novel, he has long hair and saves the Raja out of maternal love. Besides, his character allows an inversion of the mythical Radha-Krishna couple: at fourteen, he fell in love with his aunt, Taramony, and followed her as a disciple. When she turned him down, he answered: "you will be my Krishna and I will be your Radha" (149). He promises to be faithful to her, re-enacting Radha's promise to Krishna. This inversion 
of the story prefigures Babu Nob Kissin's physical transformation which is only complete after "days of dizziness, diarrhoea and vomiting" (388). Ghosh's subversion of the myth of Radha-Krishna turns Babu Nob Kissin into a grotesque figure and brings mutability to the fore as the essence of migrancy.

The narrative itself is affected by such migrancy as represented by the three parts of the novel, "Land"/"River"/"Sea." The text migrates from one character to another, and the reader is often diverted from the main plot, that is the crossing. Even though the three parts give the impression of a linear narrative, some episodes demonstrate how intricate it really is. Digressions are used to give background information on characters. This is how Babu Nob Kissin's transformation is explained for instance. On the Ibis, Neel, the Raja of Raskhali, shares his cell with a Chinese man called Ah Fatt. In the third part of the novel, the narrative takes a detour when Ah Fatt tells Neel about his home in Guangzhou. The digression is announced: "Thus it happened that while the Ibis was still on the Hooghly, Neel was being transported across the continent, to Canton - and it was this other journey, more vivid than his own, that kept his sanity intact" (345). The narrator then reports Ah Fatt's tale, in which some details might pave the way for another narrative migration. Neel thus appears as a symbolic representation of the reader who is being transported across the Indian Ocean, into an unknown territory of fiction. Besides, Ghosh relies on a poetics of expectation. All the details that are carefully worked into the text invite the reader to imagine the outcome of the characters' destiny. This is beautifully illustrated at the end when some of the characters abandon the Ibis on a raft, taking the story somewhere else. From this standpoint, Sea of Poppies presents typical signs of a diasporic novel with its worried migrants and new identities to define. The narrative focuses on the dispersal of the characters, even if they all board the same ship. Each character allows Ghosh to depict the diasporic experience as multifaceted. What prevails in this first volume is the sense of separation from the mother country and from traditions, while River of Smoke, the second volume of the planned trilogy, really underlines the coming together of different cultures depicting a cosmopolitan Asia. Yet, if the motif of the diaspora affects the story, the implications seem to exceed the narrative itself. In an essay on the Indian diaspora, Ghosh wrote that "India exported with her population, not a language, as other civilizations have done, but a linguistic process - the process of adaptation to heteroglossia" (Incendiary 246). The novel emerges then as a heteroglossic space where language stands for the epitome of migrancy.

\section{Linguistic migrations}

The linguist Émile Benveniste explains that ancient and modern languages are made of borrowed words, and that most of these words travelled from one tongue to another in sometimes unexpected ways (234). He conjures up the idea of a map, of a geographic migration of words which echoes the stories of words in Ghosh's Ibis Chrestomathy. It is said to be have been written from the point of view of the Raja of Raskhali, a pundit, a scholar fascinated by words who embodies Ghosh himself - a writer whose work sometimes deters readers. A chrestomathy is a selection of useful (from the Greek khrestos) passages to help understand or learn a foreign language. Yet, 
if The Ibis Chrestomathy partly collects definitions, it is not essentially an aid to reading. It is given to the reader more as a reflection on the migration of language than as a glossary. To Ghosh, "[i]t is devoted to a select number among the many migrants who have sailed from eastern waters towards the chilly shores of the English language" (Chrestomathy 1). In Ghosh's heteroglossic space, each language could then be seen as a continent, each represented on the Ibis, where it undergoes various types of friction. Benveniste also puts forth another dimension of the linguistic migration, taking into account the fact that every language has a past. Ghosh's novel combines these two types of linguistic mobility, acknowledging the evolution of language through types of characters. Ghosh thoroughly researched his novel, reading dictionaries and exploring the archives held at the Mahatma Gandhi Institute in Mauritius, to be able to give the closest idea of how people lived and talked at the time the novel is set. His characters can then be analysed as social types revealing a historical backdrop. They are signs for the reader to decipher, and their language, a riddle.

The novel conjures up the image of Édouard Glissant's maze of languages (114). Glissant argues that a language is never isolated. Even a writer who speaks only one language still writes under the influence of the images conjured up by other languages. ${ }^{2}$ Ghosh willingly gives in to the other languages he knows when he writes. His tongue is truly creolised as it is shaped by a diversity of idioms. The reader comes across Bhojpuri, Bengali, Babu English and much more. But reading the novel one is most struck by the indianisation of English. As Lise Guilhamon shows in her analysis of language in the Indian novel written in English, language needs to be considered from the standpoint of otherness. She insists that vernacular languages deeply transform the English text, creating what some critics call "English Masala.", Indianized English pervades Rushdie's fiction for example. Guilhamon underlines that Doughty's English is reminiscent of Kipling's “The Three Musketeers" (1888). Burnham has been living in India for about twenty-five years. Like him, the British characters in the novel all speak a language that reflects how they tried to adapt. This intermixing of languages plays two key roles throughout the novel: Ghosh uses it to explore the colonial relationship, and the characters' individual languages bring comic relief which allows for critical distance. Mrs. Burnham's English is peppered with vernacular: "Look at me, rattling on like a gudda when I should be getting on with the tumasher" (192), or else, "The kubber is that there's more than one young missymem who's got a mind to bundo the fellow" (194). What is even more revealing of the linguistic migration in the text is the way these characters try to bend foreign

2. "Nowadays, even when a writer does not speak any other language than his own, he writes, sometimes without being aware of it, under the influence of the languages that surround him. One cannot write in one tongue in a monolingual way." (My translation of "Aujourd'hui, même quand un écrivain ne connaît aucune autre langue, il tient compte, qu'il le sache ou non, de l'existence de ces langues autour de lui dans son processus d'écriture. On ne peut écrire une langue de manière monolingue” [Glissant 112].)

3. "The new forms of English being shaped in the Indian novel in English are the result of vernacular strata working their way though the text, in a hybridisation process that some critics have attempted to define as "Masala English." English then bends to some characteristics of the Indian languages such as lexical, morphological and syntactic." (My translation of "Les nouvelles formes d'anglais qui sont ainsi élaborées par le roman indien anglophone sont profondément travaillées par le substrat vernaculaire, un processus d'hybridation que certains critiques ont tenté d'exprimer à travers le vocable 'Masala English': l'anglais adopte alors certaines caractéristiques lexicales, morphologiques ou syntaxiques des langues indiennes" [Guilhamon 230].)

4. Gudda means donkey, and tumasher, dinner party.

5. Kubber means news, rumours, and bundo, tie. 
words to fit English grammar. For instance they use verbal nouns: "From what I hear, the Rascal's going to be in for a samjaoing ${ }^{6}$ soon enough" (45). The -ing inflexion is grafted on the foreign word with no other modification, the foreign verbal form being assimilated as regular infinitive. Another example of this process is when the verb is taken as a noun: "Wasn't he on the schooner when you went over to take a dekko last week?" (194).

This language is mainly based on orality and how words were heard by the colonisers: Doughty does not say Brahmaputra but Burrempooter. His pronunciation also betrays disgust: he justifies the need to speak some words of vernacular because it means being more powerful, but at the same time, it remains a corruption, a "defilement of language" (266). The way he addresses the Raja of Raskhali enlightens this duality. The Raja's name is Neel Ratan, but Doughty addresses him as Nil Rotten which hints at the corruption underlying the relation between the Empire and the Rajas. Under the British rule, Rajas collected taxes for the Empire in exchange for their title, which is why Doughty complains: "It's not as if he's real nobility, mind: the Rascallys call themselves Rogers, but they're just Ryes with an honorary title bucksheesh for loyalty to the Crown" (44). His accent conjures up the image of rascals, further undermining the status of the Raja. Pronunciation and onomastics craftily signal fraudulent colonial relationships. Moreover, when Mr. Doughty, who is not so brave in spite of his name, calls Babu Nob Kissin "Baboon," Ghosh not only points to the mimicry which is at stake for the colonial migrants, but also exposes racism.

Among the Westerners, Paulette Lambert stands out as the archetypal migrant. Born on a ship, her life has always been at the crossroads of cultures. The daughter of a French botanist, she was raised by a local woman. She embodies the very essence of métissage. "The first language she learnt was Bengali, and the first solid food she ate was a rice and dal khichri" (62). The first solid food here represents a ritual of hybridisation. Ghosh, like many postcolonial writers such as Jhumpa Lahiri or Monica Ali, uses food as a marker of identity. Paulette also learnt French which makes her one of a kind in the narrative. When she boards the Ibis, it is posing as a Bengali woman, wearing a sari, her skin painted with henna, and her face hidden by large jewels. She is with Mrs. Burnham one of the main comic figures of the novel. Her unusual upbringing has created a unique idiolect mixing English and French: "Often, when at loss for a word, Paulette would borrow a term from the French, trusting that it would pass for English if pronounced exactly as it was spelled" (235). Her sentences are not always correctly structured for she applies both French and English grammar rules. The syntactic oscillation reflects a constant migration of language. She uses the progressive form of verbs with French words such as sortie (outing): "you have been sortieing" (233); and sometimes she uses the French order of words, as in "I you assure" (251). Most of the time this habit results in comic misunderstandings.

When Paulette and Mrs. Burnham speak to one another, the comic potential of the novel is catalysed. After the dinner hosted at Bethel, the Burnhams' estate, Mrs. 
Burnham announces to Paulette that Judge Kendalbushe is about to propose. Paulette protests for she fancies Zachary:

'But one cannot learn to love, Madame [...].[S]urely it is more like a coup de foudre how do you say in English - like being shot by his bolt.'

'Shot by his bolt!' Mrs Burnham clapped her hands over her scandalized ears. 'Puggly! You must really watch what you say.' (253)

The innocence of Paulette's coup de foudre (love at first sight) is undermined by the sexual innuendos perceived by Mrs. Burnham. The misunderstanding between the two women goes on for the rest of their conversation and Mrs. Burnham ends up believing that Paulette is pregnant: "Puggly...!' Mrs Burnham gasped, fanning herself with a pillow. 'Oh my dear! Oh heavens! Tell me Puggly: I must know the worst. [...] Puggly tell me the truth, I conjure you: there isn't a rootie in the choola, is there?"' (254) Mrs. Burnham literally transposes the expression "a bun in the oven" to her domestic reality, thus reinforcing Paulette's confusion:

Paulette was a little surprised to see Mrs Burnham making such a to-do about a matter she usually touched upon so lightly - but she was glad, too, to have the conversation turned in this new direction, since it presented a good opportunity for escape. Hugging her stomach, she made a moaning sound: "Madame, you are perfectly right: I am indeed a little foireuse today." (254)

Mrs. Burnham's relexification, to borrow a term coined by Chantal Zabus, and Paulette's mixed-up vocabulary create an even wider gap for the reader who has no knowledge of one of the languages. But the Babel effect is yet heightened by another group of characters: the lascars.

[T] hey came from places that were far apart, and had nothing in common, except the Indian Ocean; among them were Chinese and East Africans, Arabs and Malays, Bengalis and Goans, Tamils and Arakanese. They came in groups of ten or fifteen, each with a leader who spoke on their behalf. To break these groups was impossible; they had to be taken together or not at all. (13)

The hybridity of their sociolect is a necessity. Adopting the anthropologist's stance, Ghosh exposes their drifting tongue:

Laskari - that motley tongue, spoken nowhere but on the water, whose words were as varied as the port's traffic, an anarchic medley of Portuguese calaluzes and Kerala pattimars, Arab booms and Bengal paunch-ways, Malay proas and Tamil catamarans, Hindustani pulwars and English snows. (96)

Serang Ali, the chief of the lascars, embodies the instability of their language. Some patterns recur like the repetitions as in "chin-chin" (15), "buk-buk, big-big" (16), "same-same" (409). But the standard syntax has disappeared: "Only cause of Malum Zikri, Serang Ali come on Ibi. Or else not come” (410). The lascars' tongue reveals an urge to adapt. The traditional syntax gives way to shortcuts of meaning. For instance, sometimes the grammatical subject is eluded: "If planter-bugger coming catch, must do dumbcow" (19). Besides, the instability in the spelling, as in "nevva" (15)/ "nebba" (18), emphasises Laskari as a drifting tongue. Language thus appears as unstable. Furthermore, before boarding the Ibis, the coolies have to be registered. This is how Deeti/Aditi becomes Aditty, and Madhu, Maddow Colwer. "Those hallowed names were the result of the stumbling tongue of a harried gomusta, and the faulty hearing of 
an English pilot who was little more than half-seas over" (262). The urge of migrancy is reflected in the change of names, the very symbol of identity, and the way names migrate epitomises the way language is transformed. The Ibis may be compared to the Plantation as analysed by Glissant: it is a closed place where language is not restricted (Poétique 77). On board, characters claim their identity speaking their language, telling their story over and over. But this closed space is also where they experience otherness. Similarly, the book is the space wherethe reader is confronted with the alterity of language.

\section{Migrant reading}

Mr. Doughty refers to the "zubben" which he defines as "the flash lingo of the East" (Sea of Poppies 45). But this lingo which pervades the text sometimes represents a limbo of meaning for the reader. The novel teems with languages. French words used by Paulette and other foreign words used by the lascars and the British appear in the text without italics. On the other hand, vernacular languages such as Bhojpuri are italicised and even glossed sometimes. Yet, there is no definite pattern to the writing, nor therefore to the reading. For instance, non-English words related to food, clothing and rituals are blended in the text. In the incipit, the reader comes across "rotis," "achar," and "puja" (3), which creates a double sense of dislocation/relocation. These words transport the reader into foreign territory. Not using English words for cultural references is common enough among postcolonial writers. Vernacular words left unglossed, and even French words used by Paulette, to a non-francophone readership, create a distance between the text and the reader, alluding to a particular cultural environment. The reader then becomes an interpreter of signs. Crossing the Kala-Pani for the reader means coping with the metonymic gaps opened by these words. The black water is a metaphoric reflection of the ink on the page. The novel conjures up the image of an ocean of words, where limits are difficult to draw. Ghosh speaks many languages himself, and even grew up with Bhojpuri. ${ }^{8}$ In an interview with Christopher Lydon, he explains that all these languages coexist in his mind as in a porous space and that he "can't really draw a line between them" ("Amitav Ghosh and his Sea of Poppies").

When the coolies speak in Sea of Poppies, Ghosh intersperses English with their language in the dialogues, "cushioning" the foreign words, to use Chantal Zabus's term for "contextualizing." Deeti's cues in the dialogues are written mostly in Bhojpuri and in italics, with a translation. This is a way to emphasise the coolies' condition as migrants while also a way to make their language more readily understandable to the reader. Using their tongue emphasises the local focus, their origin. As in other novels by Ghosh, this strategy mainly aims at enticing the reader to be vigilant. Italics are not systematically used. When Deeti glimpses at the Ibis in her vision, she tells her daughter: "Beti - I saw a jahaj - a ship" (8). A couple of pages later, the same word appears in italics with a different spelling: jahaz (67). About the use of Bengali words in The Hungry Tide, Christopher Rollason uses the term "foreignising strategy" (2). Sea of Poppies relies on a similar approach for if one

8. Bhojpuri is a language spoken in western Bihar and eastern Uttar Pradesh. In Mauritius, it is one of the Indian languages that are still spoken, along with Tamil. 
considers languages as continents, vernacular words lead the reader to a sort of terra incognita. Each untranslated word makes the text even more foreign to the reader. The narrative is then made of new linguistic territories to discover.

Usually foreign words are used in dialogues. But here, the narrative voice is contaminated by vernacular and slang idioms. As soon as a word is explained, or even just uttered sometimes, it is then grafted on the narrative. In the first chapter, the narrator exposes a couple of new words Zachary has to get used to: "He had to learn to say 'resum' instead of 'rations', and to wrap his tongue around words like 'dal', masala' and 'achar'. He had to get used to 'malum' instead of mate, 'serang' for bosun, 'tindal' for bosun's mate, and 'seacunny' for helmsman" (14). In the next paragraphs, "tindal" and "serang" appear on their own with no typographic signal. Even though foreign locutions make the text complex, they do not make it cryptic. The immediate context very often provides the reader with clues to make up for the "lost meaning." What is surprising however is the density of foreign words in the text. They are repeated through the narrative, especially those with a nautical connotation, thus acquiring a haunting presence which enforces meaning. The Ibis Chrestomathy, which was published after the novel on Ghosh's official website, points to this active reading, but also to a migrant reader. The reader's potential to-and-froing between the Chrestomathy and the novel stands for the journey and search for meaning. The profusion of foreign words makes it hard for the reader to follow the various semantic threads they form through the narrative. The text may then be perceived as an unfinished tapestry. Some words and references create blanks that the reader will fill in, looking for the missing information, or fantasising about the images they conjure up through sound. For example, the "karibat" Doughty is eager to eat might evoke the image of curry if one reads the text aloud.

Globalisation is a recurring theme in Ghosh's writing, both fiction and non-fiction, synonymous not with uniformity but hybridisation. His characters are mostly migrant, in-betweeners even. In Sea of Poppies, Ghosh tackles the issue of globalisation from the standpoint of indentured labour. Introducing Zachary in the narrative and pointing out that the Ibis was a former slave-ship, he shows that the coolies were indeed "faceless migrants" (Chambers 38) to the colonial institutions. These migrants are given names and a history in the novel, which emphasises how dislocation served global interests. Each character represents a local identity and when they board the Ibis they become part of the anonymous crowd of workers who helped shape the Empire. Ghosh insists on the power of the opium trade as a catalyst of the métissage of cultures. And even though he enlightens the coolies' suffering and inner conflicts, he does not give a pessimistic image but a nuanced approach of this diaspora. This angle is what makes Sea of Poppies stand out as a diasporic novel rather than a global novel. What is at stake is the sense of exile, as the narrative dwells on the characters' struggle to keep their memories of home vivid. In many ways, the novel is more about how they try to come to terms with change rather than change itself. Still, diaspora appears as a preliminary step toward globalisation, which is thoroughly discussed in the second volume of the trilogy. Here, local identities are uprooted and translated to merge, while being reshaped along the way. To expose how the diasporic movement deeply affected people's identity, Ghosh focuses on language. Sea of Poppies is imbued with linguistic inventiveness of a new kind which highly contrasts with Salman Rusdhie's or 
Arundhati Roy's. Ghosh does not invent words, but tries to resurrect forgotten idioms such as Laskari. With this enthralling and challenging novel, he chooses to embrace the diversity of the Indian sub-continent, renewing the ways of looking at the colonisers in the process. He craftily weaves together English Masala, Babu English, Bhojpuri, Bengali, Laskari and French. Choosing to focus on migrant people, Ghosh illustrates how language is linked to identity and power, for here, people define themselves through language. With an anthropologist's focus, the novel digs out a history of how languages are constantly reshaped, and thus become truly cosmopolitan. As Bishnupriya Ghosh puts it, "now readers are asked to perform different acts of translation on a case-by-case basis, to migrate between cultural and linguistic worlds whose boundaries are not rigorously defined as East-West or postcolonial-colonial" (119). Re-mapping the Indian Ocean around the opium and coolie trades, Ghosh thus takes his readers on a journey to new and forgotten languages, given as traces to be deciphered of past migrations

\section{Sabine LAURET, University of Paris Est-Créteil}

\section{Works Cited}

APPANAH, Nathacha. Les rochers de Poudre d'Or. Paris: Gallimard, 2003.

BENVEnISTE, Emile. Problèmes de linguistique générale 2. 1974. Paris: Gallimard, 2005.

BoEHMER, Elleke. Colonial and Postcolonial Literature. $2^{\text {nd }}$ ed. Oxford: Oxford UP, 2005.

CAstaing, Anne, Lise GuilHAMON and Laetitia ZECCHINI. La modernité littéraire indienne : perspectives postcoloniales. Rennes: Presses Universitaires de Rennes, 2009.

Chambers, Claire. "Representations of the Oil Encounter in Amitav Ghosh's The Circle of Reason." The Journal of Commonwealth Literature 41.1 (2006): 33-50.

Dixon, Robert. "“Travelling in the West': The Writing of Amitav Ghosh." Amitav Ghosh: A Critical Companion. Ed. Tabish Khair. Delhi: Permanent Black, 2003. 9-35.

Ghosh, Amitav. "Amitav Ghosh and his Sea of Poppies." A Conversation with Christopher Lydon. 21 July $2011<$ http://www.radioopensource.org/amitav-ghosh-and-his-sea-of-poppies/>.

—. "The Diaspora in Indian Culture." The Imam and the Indian. New Delhi: Ravi Dayal, 2003.

—. Incendiary Circumstances: A Chronicle of the Turmoil of our Times. Boston: Houghton Mifflin, 2005.

—. River of Smoke. London: John Murray, 2011.

—. Sea of Poppies. London: John Murray, 2008.

GHosh, Bishnupriya. When Borne Across, Literary Cosmopolitics in the Contemporary Indian Novel. New Brunswick: Rutgers UP, 2004.

GLISSANT, Édouard. Introduction à une poétique du divers. Plessis-Trévise: Gallimard, 2006.

-. Poétique de la Relation. Paris: Gallimard, 1990.

MeTHA, Brinda. Diasporic (Dis)locations: Indo-Caribbean Women Writers Negotiate the Kala Pani. Jamaica: U of West Indies P, 2004.

MishrA, Vijay. The Literature of the Indian Diaspora: Theorizing the Diasporic Imaginary. London: Routledge, 2007.

ROLLASON, Christopher. "In our translated world': Transcultural Communication in Amitav Ghosh's The Hungry Tide." 3 June 2010 <http://www.seikilos.com.ar/ghosh.pdf>.

RusHDIE, Salman. The Enchantress of Florence. New York: Random, 2008.

Zabus, Chantal. The African Palimpsest: Indigenization of Language in the West African Europhone Novel. Amsterdam: Rodopi, 1991. 